\title{
Infant Multiple Mandibular Fracture: Case Report
}

\author{
Fractura Múltiple Mandibular en Infante: Reporte de Caso
}

\author{
Letelier Claudia*; León Matilde*; Boesing Lucinéia*; Ortega Rodolfo* \& Pantoja Roberto*
}

LETELIER, C.; LEÓN, M.; BOESING, L.; ORTEGA, R. \& PANTOJA, R. Infant multiple mandibular fracture: Case report. Int. J. Med. Surg. Sci., 3(2):823-827, 2016.

SUMMARY: Infant facial fracture incidence is low. Most reported cases affect the jaw and are single fractures. We present a twenty-two-month old patient, who had a high-energy car accident. Among other injures, she suffered a multiple mandibular fracture: bicondylar, left body and right parasymphyseal. Stable internal fixation of parasymphyseal and body mandibular fracture was performed on the third day. Condylar fractures had a functional treatment with switching elastic traction to prevent ankylosis. Computed tomography (CT) showed mandibular condyles remodelling after six months. Clinical examination showed that mandibular movement ranges were preserved without alteration. Successful treatment of paediatric patients is based on the achievement of an adequate anatomic reduction and the stability of the fracture, allowing opportune form and function recovery, in order to assure further development of dental and facial structures.

KEY WORDS: Multiple fractures; Mandibular fracture; Infant.

\section{INTRODUCCIÓN}

Incidence of facial fractures in paediatric patients is low, particularly when it affects children under two years old and it represents between 0.9 and $2.6 \%$ of the cases (Haug \& Foss, 2000; Chidzonga, 2006). This low percentage is due to a reduced exposure to causative factors because of parental protection (Knoche et al., 2012; Vasconcelos et al., 2009; Glazer et al., 2011; Muñante-Cárdenas et al., 2011) and the bones anatomical characteristics that are of greater elasticity. Despite this low incidence, many cases of infant mandibular fractures are referred to in papers, being $96 \%$ single fractures and $4 \%$ double fractures (Knoche et al.; Chidzonga; Yen et al., 2004). We present the case of a patient of this age group with multiple mandibular fractures, which has not been previously reported.

\section{CASE REPORT}

A 22 months old patient, with no morbid record who had a car accident, was expelled in her mother's arms through the windscreen after crashing against a road barrier. She was found conscious, ten meters away from the car and then taken to the emergency of the Hospital Clínico San Borja Arriarán (HCSBA), SantiagoChile. During the physical examination the patient was connected, Glasgow scale 15, she had a right periorbital ecchymosis, severe right hemifacial edema, erosive facial injuries, erosive chin wound (Fig. 1), blunt cutting wound in the inner side of the lower lip, gingival wound of upper front teeth zone, avulsion of 52 and 53 teeth, luxation of 51 and 61 teeth. Diagnosis was carried out after multidisciplinary evaluation: uncomplicated closed cranio-

\footnotetext{
* Unidad de Cirugía Maxilofacial, Hospital Clínico San Borja Arriarán, Departamento de Cirugía Maxilofacial, Universidad de Chile, Santiago, Chile.
} 
encephalic trauma, uncomplicated abdominal contusion, traumatic dental injuries and multiple mandibular fractures. The images of computed tomography (CT) revealed bicondylar, left body and right parasymphyseal mandibular fracture and alveolar fracture in the area of upper incisors (Fig. 2). Patient remained in intensive care unit where cleaning and disinfection of wounds was done; antibiotic treatment was indicated with intravenous cefazolin

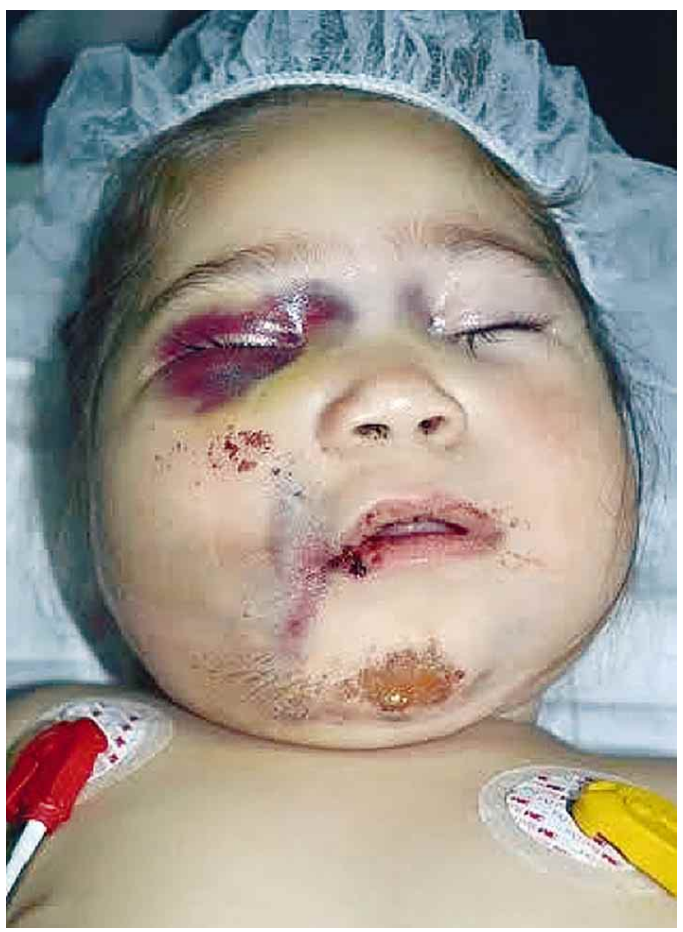

Fig. 1. Pre-surgical appearance. and analgesia. Three days after the accident the following interventions were performed: internal fixation with miniplates and screws in the parasymphyseal and body mandibular fracture was made (Fig. 3), the lip and gingival wound were sutured, splinting of inferior-anterior teeth was performed to facilitate the functional treatment of condylar fractures. Moreover, a screw was inserted into the maxillary midline just below the anterior nasal spine (to raffle permanent tooth germs) so that an elastic traction was performed between this screw and the mandibular splint (Fig. 4). Facial CT showed good postoperative fracture reduction. Functional treatment began by alternating elastic traction switching sides every four hours during the day in order to produce contralateral movements of condyles. Elastics were removed at night. This treatment lasted more than a month after leaving hospital. Three months later facial CT showed remodelling of mandibular condyles (Fig. 5) and on the sixth month during clinical examinations laterality and opening ranges were preserved, without deviation from the midline (Fig. 6).

\section{DISCUSSION}

Mandibular fractures treatment planning of infants should be based on anatomy and physiology knowledge of the region. The objectives are to restore function and form with minimal morbidity (Glazer et al.; Bast, 2009; Ellis \& Throckmorton, 2005). The main aim is to preserve mandibular mobility, allowing normal growth of the condylar skeletal units, given the secondary nature of their cartilage. The function will prevent the occurrence of temporomandibular ankylosis, one of the most serious

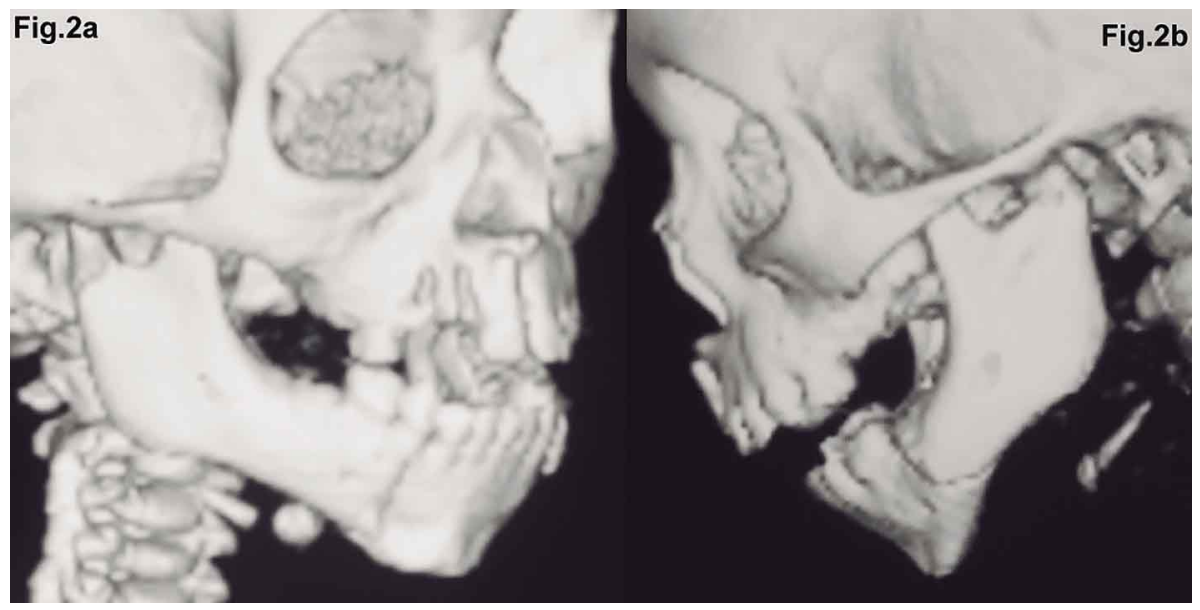

Fig. 2. a) Right condylar and parasymphyseal mandibular fracture. b) Left condylar and body mandibular fracture. 


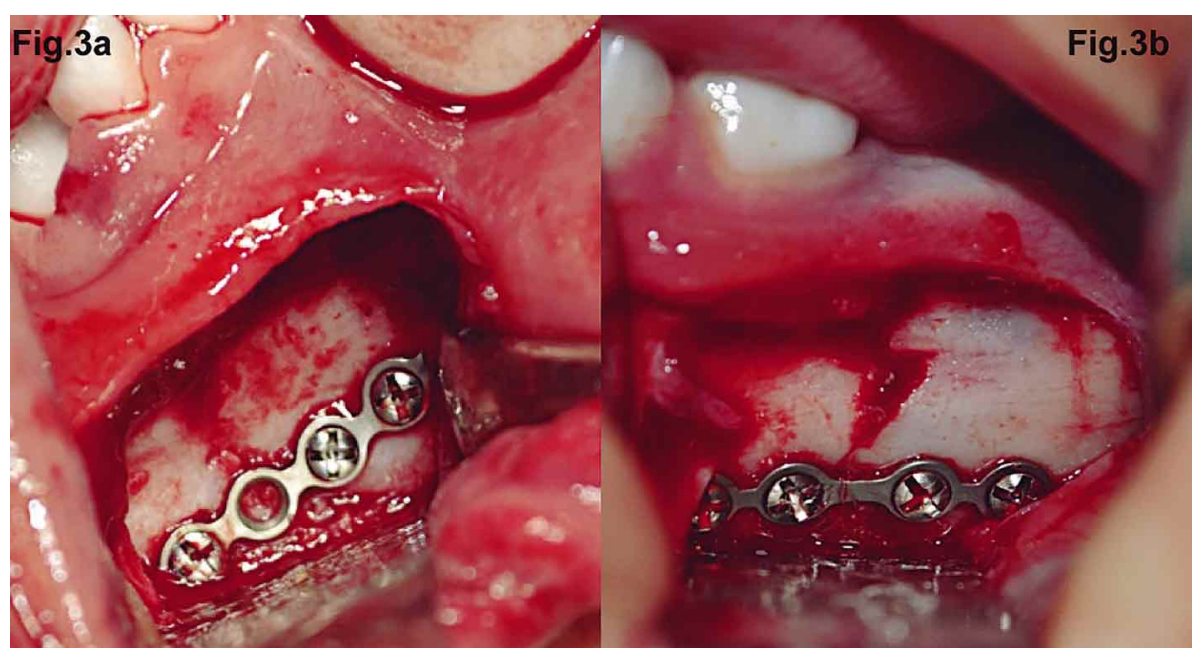

Fig. 3. a) Right parasymphyseal fracture, reduction and osteosynthesis. b) Left body mandibular fracture, reduction and osteosynthesis.

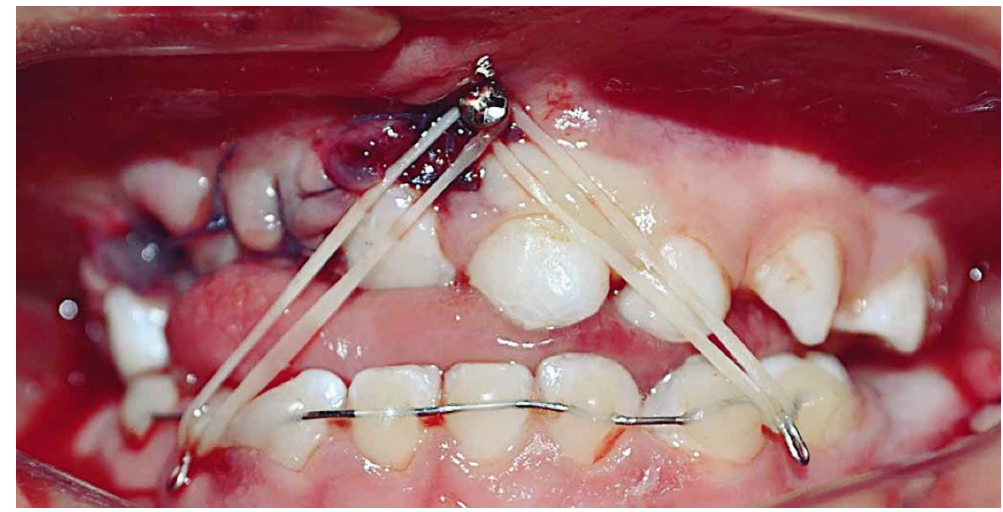

Fig. 4. Maxillar screw and mandibular dental splint for elastic traction.

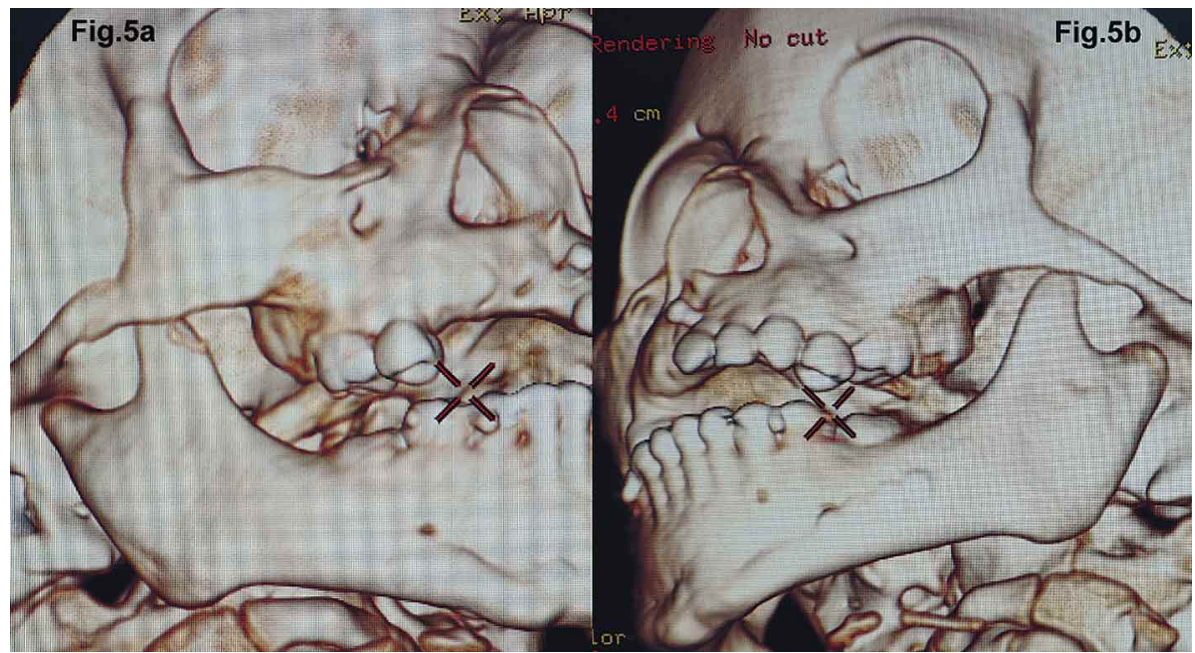

Fig. 5. CT after 3 months of treatment. a) Right side. b) Left side. 
complications of condylar fractures. Another function that must be recovered is an adequate dental occlusion.

Paediatric patients have more elastic connective tissue, an increased osteogenic potential and a faster tissue repairing due their better vascularization. Therefore their fracture healing time is less and anatomical reduction should ideally be achieved within the first four days (Haug \& Foss; Glazer et al.; Muñante-Cárdenas et al.; Bast; Herford \& Punjabi, 2004).

Therapeutic possibilities of condylar fractures are functional, orthopedic, surgical or mixed (Haug \& Foss; Bast; Herford \& Punjabi; Sharif et al., 2010). The treatment is defined considering the characteristics of each case, growth stage and development of the patient, the presence of teeth and tooth germs, as well as the therapeutic options available, among others. Whenever possible functional treatment is indicated to children younger than ten years of age with mandibular condyle fracture. This is possible thanks to the high morphological and functional condyle capacity of regeneration, as long-term clinical and experimental studies confirm (Bast; Ellis \& Throckmorton; Kotecha et al., 2008; Singh et al., 2010). Independently from the severity of the fracture, after an early, maintained and a good quality functional treatment, an operative condyle generation is achieved, with its new head in the mandibular fossa (Ellis \& Throckmorton; Caubet Biayna et al., 2014).

The fractures, in this case, occurred in two different units of the mandibular skeletal complex. Condylar fracture required early mobilization and body fracture needed adequate fixation and immobilization. Therefore, surgical treatment of body and parasymphyseal fractures was made so as to stabilize the jaw, to allow early mobilization of temporomandibular joint and to reduce ankylosis risks.

Currently, due to possible alterations that titanium plates may cause in growing and development patients, the maintenance of them is controversial. One approach considers that plates must be removed after 2-3 months; another proposes to maintain osteosynthesis material unless a real alteration is observed. On one hand, the latter is based on biocompatibility of titanium. And on the other hand, there is no scientific evidence to establish a causal relation between the presence of titanium plate and changes in facial bone growth (Muñante-Cárdenas et al.; Bast). It is important to mention that there is a risk of intraosseous translocation of plates because of mandibular growth, which makes difficult their removal, if required (Haug \& Foss; Vasconcelos et al., 2009; Bast).

The mandibular function is essential for dentofacial growth and development. When there are mandibular fractures in young children it is important to ensure a proper reduction and stabilization, as well as to provide the conditions for early and normal mandibular mobility, which is the main morphogenetic agent of the lower third of the face.

DISCLOSURE OF CONFLICT OF INTEREST: The authors report no conflicts of interest in this work.

LETELIER, C.; LEÓN, M.; BOESING, L.; ORTEGA, R. \& PANTOJA, R. Fractura múltiple mandibular en infante: Reporte de caso. Int. J. Med. Surg. Sci., 3(2):823-827, 2016.

RESUMEN: La incidencia de fracturas faciales en infantes es baja. Los casos reportados muestran que afectan principalmente a la mandíbula y corresponden a fracturas únicas. Presentamos una paciente de 22 meses de edad, que sufre accidente automovilístico. Resulta entre otros, con múltiples fracturas mandibulares: bicondílea, de cuerpo izquierdo y parasinfisiaria derecha. Al tercer día se realiza fijación interna estable en fractura parasinfisiaria y de cuerpo mandibular y tratamiento funcional de las fracturas condíleas a través de tracción elástica alternada, para prevenir la anquilosis. Tomografía computada a los seis meses muestra remodelación de los cóndilos mandibulares. Al examen clínico los rangos de movimiento mandibular están conservados y sin alteración. El éxito del tratamiento en pacientes pediátricos se basa en obtener una adecuada reducción anatómica y estabilidad de la fractura, que permita recuperar oportunamente forma y función, asegurando el futuro desarrollo de las estructuras dentarias y faciales.

PALABRAS CLAVE: Fractura multiple; Fractura mandibular; Infante. 


\section{REFERENCES}

Bast, B. Injuries to the Mandibular Condyle and Subcondylar Region. In: Fonseca, R. J.; Marciani, R. D. \& Turvey, T. A. Oral and Maxillofacial Surgery. Volume II: Trauma, Surgical Pathology, Temporomandibular Disorders. St. Louis (Mo.), Saunders/Elsevier, 2009.

Caubet Biayna, J.; Iriarte Ortabe, J. I.; Morey Mas, M.; García-Rozado González, A.; Jiménez Rubio, J. A. \& Portaceli Roig, T. Capítulo 13: Fracturas Condileas. En: Protocolos Clínicos de la Sociedad Española de Cirugía Oral y Maxilofacial. Madrid, Sociedad Española de Cirugía Oral y Maxilofacial, 2014. pp.195-9.

Chidzonga, M. M. Mandibular fracture in a neonate: report of a case. Int. J. Oral Maxillofac. Surg., 35(2): 186-7, 2006.

Ellis, E. \& Throckmorton, G. S. Treatment of mandibular condylar process fractures: biological considerations. J. Oral Maxillofac. Surg., 63(1):115-34, 2005.

Glazer, M.; Joshua, B. Z.; Woldenberg, Y. \& Bodner, L. Mandibular fractures in children: analysis of 61 cases and review of the literature. Int. J. Pediatr. Otorhinolaryngol., 75(1):62-4, 2011.

Haug, R. H. \& Foss, J. Maxillofacial injuries in the pediatric patient. Oral Surg. Oral Med. Oral Pathol. Oral Radiol. Endod., 90(2):126-34, 2000.

Herford, A. \& Punjabi, A. Mandibular Fractures. In: Thaller, S. R. \& McDonald, W. S. Facial Trauma. New York, Marcel Dekker, 2004.

Knoche, J. W.; LeBlanc, K. K.; King, T. W. \& Knox, B. L. An infant with a unilateral mandibular fracture: when to consider nonaccidental trauma. Clin. Pediatr. (Phila.), 51(4):404-7, 2012.

Kotecha, S.; Scannell, J.; Monaghan, A. \& Williams, R. W. A four year retrospective study of 1,062 patients presenting with maxillofacial emergencies at a specialist paediatric hospital. Br. J. Oral Maxillofac. Surg., 46(4):293-6, 2008.

Muñante-Cárdenas, J. L. ; Olate, S.; Asprino, L.; de Albergaria Barbosa, J. R.; de Moraes, M. \& Moreira, R. W. Pattern and treatment of facial trauma in pediatric and adolescent patients. J. Craniofac. Surg., 22(4):1251-5, 2011.

Sharif, M. O.; Fedorowicz, Z.; Drews, P.; Nasser, M.;
Dorri, M.; Newton, T. \& Oliver, R. Interventions for the treatment of fractures of the mandibular condyle. Cochrane Database Syst. Rev., (4):CD006538, 2010.

Singh, V.; Bhagol, A.; Goel, M.; Kumar, I. \& Verma, A. Outcomes of open versus closed treatment of mandibular subcondylar fractures: a prospective randomized study. J. Oral Maxillofac. Surg., 68(6):1304-9, 2010.

Vasconcelos, B. C.; Lago, C. A.; Nogueira, R. V.; Gondim, D. G., \& Brito Filho, A. Mandibular fracture in a premature infant: a case report and review of the literature. J. Oral Maxillofac. Surg., 67(1):218-22, 2009.

Yen, S. L.; Don, D. ; Pollack, S. \& Yamashita, D. D. Closed reduction of a symphysis fracture in a 2month-old infant: treatment considerations. $J$. Trauma, 56(3):706-8, 2004.

Dirección para Correspondencia: Claudia Oriette Letelier Fuentealba

Address: Avenida Santa Rosa 1234

Santiago, Región Metropolitana

CHILE

Phone: 58-9-95799704

Email: cletelierfuentealba@gmail.com

Received: 14-04-2016

Accepted: 22-05-2016 